\title{
PENGARUH MODEL PROBLEM BASED LEARNING (PBL) TERHADAP HASIL BELAJAR SISWA PADA MATERI POKOK SUHU DAN KALOR DI KELAS X SEMESTER II SMA NEGERI 11 MEDAN T.P. 2014/2015
}

\author{
Purwanto ${ }^{1)}$ dan Seri Siregar ${ }^{2)}$ \\ Jurusan Fisika FMIPA Universitas Negeri Medan \\ serisiregar3@gmail.com
}

\begin{abstract}
ABSTRAK
Penelitian ini bertujuan untuk mengetahui pengaruh model Problem Based Learning (PBL) terhadap hasil belajar siswa pada materi pokok Suhu dan Kalor di Kelas X Semester II SMA Negeri 11 Medan T.P. 2014/2015. Jenis penelitian ini adalah quasi eksperimen. Populasi dalam penelitian adalah seluruh siswa kelas X SMA Negeri 11 Medan. Penarikan sampel dengan cluster random sampling yaitu X-3 sebagai kelas eksperimen dengan pembelajaran Model Problem Based Learning sedangkan kelas X-4 sebagai kelas kontrol diajarkan dengan pembelajaran Konvensional. Instrumen yang digunakan pada penelitian adalah tes pilihan berganda 20 soal dari 25 soal yang telah diuji validitasnya. Data penelitian yaitu dalam bentuk hasil belajar .Untuk data hasil belajar diawali dengan uji normalitas dan homogenitas. Dengan data yang sudah telah berdistribusi normal dan homogen maka dilk kukan uji statistik dengan uji t pada taraf signifikan $\alpha$ $=0,05$. Nilai rata-rata hasil prete ketas eksperimendalah 39,5 dan kelas kontrol adalah 38,25. Dan nilai rata-rata postes keles eksperimen 76,63,dan kelas Montrol 67,63. Hasil uji t satu pihak $\mathrm{H}_{a}$ di terima $t_{\text {hitung }}>t_{t a},(4,84,51,667)$, maka kesimpatan darn asil uji t ada pengaruh model Problem Based Lec ning rernadap hasil belaiar siswa padamateri pokok Suhu dan Kalor di kelas Kata kunci : Problemis Based Lea researc was atmed ABSTRACT

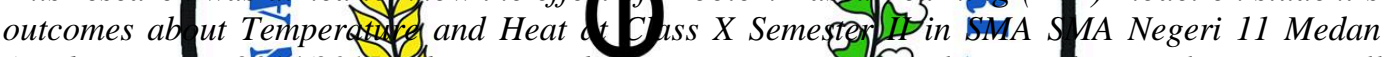

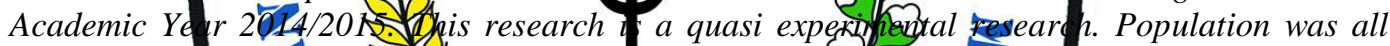
student class of 1 Medan. S Impling method wesd cluster r ndom sampling, which

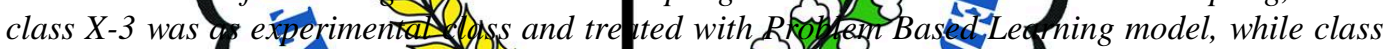

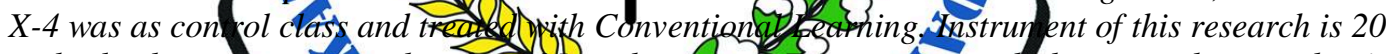

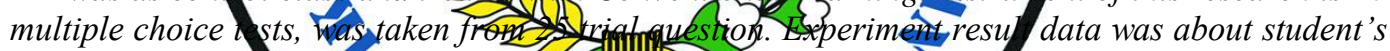
outcomes. Norma ty and homogeneity bf datd $\mathrm{was}$ firstly tested. Thd normal and homogenous data was tested by $\mathrm{u}$.ng parametric t-test with_significance level $\alpha$ 0,05. Mean of pre-test result

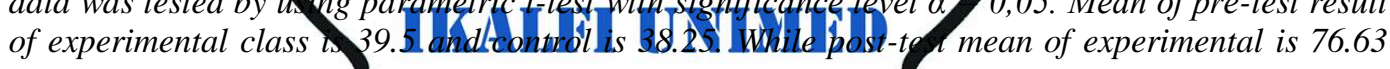
and control is 67.63Resutrone tailed t-test ( $t_{\text {count }}=4.8-t_{\text {table }}=1.667$ ) showed that there was a significant effect of PBL moae about Temperature and Heat at Class X Semester II in SMA SMA Negeri 11 Medan Academic Year 2014/2015.

Keywords: Problem based learning, Conventional learning, and Student's outcomes
\end{abstract}

\section{PENDAHULUAN}

Pendidikan merupakan kebutuhan yang bersifat fundamental bagi manusia, dengan pendidikan manusia dapat mengembangkan dan memanfaatkan potensi yang telah diberikan oleh sang pencipta kepadanya. Mutu pendidikan di Indonesia terutama dalam mata pelajaran fisika masih tergolong rendah. Mutu pendidikan di Indonesia terutama dalam mata pelajaran fisika masih tergolong rendah. Berdasarkan hasil survey Trends in International Mathematics and Science Study (TIMSS) tahun 2007 bidang science, Indonesia menduduki peringkat 35 dari 49 negara dengan nilai 427, padahal skor rata-rata internasional adalah 500. Sedangkan pada tahun 2011, Indonesia posisinya menurun menduduki peringkat ke 40 dari 42 negara. Hasil survey tersebut tentu saja menjadi salah satu indikator mengenai kondisi dan kualitas pendidikan di Indonesia yang perlu mendapat perhatian serius untuk ditingkatkan (litbang.kemdikbud.go.id).

Rendahnya kualitas pendidikan yang dihasilkan tidak terlepas dari berbagai faktor di antaranya pengemasan pembelajaran, proses pembelajaran fisika yang berlangsung masih berorientasi pada buku teks dan ketercapaian kurikulum dengan didominasi oleh pembelajaran langsung. Pada proses pembelajaran suasana kelas cenderung teacher-centered sehingga siswa cenderung pasif dalam mengikuti pembelajaran, kurang memiliki inisiatif di kelas, dan kurang kreatif dalam berpikir. Proses pembelajaran di dalam kelas diarahkan kepada kemampuan anak untuk menghafal informasi, tanpa dituntun untuk 
memahami informasi yang diingatnya untuk dihubungkan dengan kehidupan sehari-hari.

Pendidikan yang baik di dalamnya terdapat proses belajar mengajar yang baik karena proses belajar mengajar merupakan perilaku inti dalam proses pendidikan dimana anak didik dan peserta didik saling berinteraksi.Untuk mewujudkan proses kegiatan belajar mengajar diperlukan unsur yang terpenting adalah bagaimana guru dapat merangsang dan mengarahkan siswa dalam belajar, yang pada gilirannya dapat mendorong siswa dalam pencapaian hasil belajar yang optimal, dengan belajar siswa dapat merangsang otak untuk berpikir dan berkreatifitas dalam mengarahkan perubahan tingkah laku dan pertumbuhan siswa tersebut (Dalyono,2007).

Berdasarkan hasil studi pendahuluan yang peneliti lakukan di SMA N 11 Medan pada hari Senin, 26 Januari 2015 peneliti menemukan bahwa hasil belajar fisika rendah dimana sekitar $60 \%$ siswa pada masing - masing kelas X Ilmu Alam (IPA) masih memiliki nilai Kriteria Ketuntasan Minimal sekolah tersebut yakni 75 remedial.

Hal ini sesuai dep yang disebarkan pada 40 SMA N 11 Medan, diper mengatakan pembelajaran dipahami dan membosan bahwa pembelajaran fisik: saja, dan 33\% menyatak n bahtua pethoglajaran fisika di kelas itu menank dan men atkkan. Selain itu, khusus pelajaran f ika, siswa ketal hon akan merasa bingung ketik dihadapkan de ros materi yang baru. Hal ini ka ena secara umunn pelajaran fisika memiliki dasar lasar yang wajib dipahami terlebih dahulu sebelum asuk ke materi, $\uparrow$ selanjutnya. Padahal mereka tidak pkus dengan materi sebelumnya. Hal ini tentu sangat sut bagi mereka untuk menerima. Dan akhirnya akan muncur anggapan bahwa fisika itu sulit dan membosankan ditambah lagi rumus yang begitu banyak untuk dihafal.

Ketika dilakukan pengamatan lebih lanjut ternyata metode pembelajaran yang biasanya digunakan guru dalam pembelajaran Fisika di kelas adalah metode ceramah dan diskusi/tanya jawab. Dalam proses pembelajaran dengan menggunakan metode diskusi, sebagian siswa masih sulit untuk berdiskusi dengan teman sekelompoknya. Selain itu, aktivitas belajar siswa selama pembelajaran dengan metode diskusi berlangsung cenderung didominasi oleh siswa yang memiliki tingkat pemahaman yang lebih tinggi sedangkan siswa yang memiliki pemahaman lebih rendah cenderung kurang aktif.

Wajar akhirnya bila dalam kelompok diskusi, sebagian besar siswa hanya diam, mainmain, dan bercanda. Dan akan timbul pula keengganan untuk mengajukan pertanyaan ataupun pendapat. Apalagi kurikulum terbaru, dalam hal ini kurikulum 2013, terkesan memaksa siswa untuk berorientasi pada pencapaian atau penyelesaian target materi bukan pada pencapaian pemahaman siswa secara maksimal.

Untuk mengatasi masalah tersebut, diperlukan suatu model pembelajaran yang inovatif yang dapat membangkitkan motivasi belajar siswa yang pada akhirnya dapat meningkatkan hasil belajar siswa. Salah satu model pembelajaran inovatif yang relevan dalam pembelajaran Fisika adalah model pembelajaran Problem Based Learning (PBL) yang diartikan sebagai pembelajaran berbasis masalah. Pada prinsipnya dalam model pembelajaran PBL, siswa sendirilah yang secara aktif mencari jawaban atas masalahmasalah yang diberikan guru. Dalam hal ini guru lebih banyak sebagai mediator dan fasilitator untuk membantu siswa dalam mengkonstruksi pengetahuan mereka secara efektif. Menurut Arends (2009) RBL merupakan suatu pendekatan peñbelajaran dimana siswa mengerjakan permásaląian yang qutentik dengan maksud untuk menyusun mengetabuan sendiri, angembangkä, inkuir dan keterampilan berpikir rebih tinggi, mengembangkan kemandirian diri. Pembelaja an PBL menuntut siswa aktê melakikan penyelidikan dalam

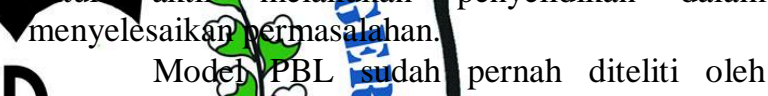

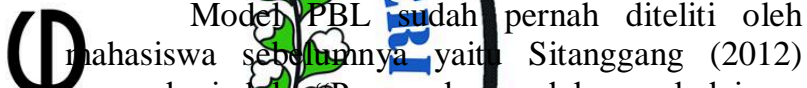
yang berjudx cupengaruh model pembelajaran berbasis masapt hlerhadap ha il belajar siswa", hasil penelitian (m) Hul o jukk has belajar siswa dengan menggynal nu nodel pembe lajaran berbasis masalah lebih dinggi dibândirgan dengan model monvensional.

Trianto (2012 menyatakan bahwa model pembelajaran berdararkan masalah (Problem Based Learning) merun kan suatu model pembelajaran yang didasaran pada banyaknya permasalahan yang moutuhkan penyelidikan autentik yakni dengan maksud untuk menyusun pengetahuan mereka sendiri, mengembangkan inkuiri dan ketrampilan berpikir tingkat lebih tinggi, mengembangkan kemandirian dan percaya diri.

Model PBL merupakan model pembelajaran dengan pendekatan pembelajaran siswa pada masalah autentik sehingga siswa dapat menyusun pengetahuannya sendiri, menumbuh kembangkan keterampilan yang lebih tinggi dan menemukan, memandirikan siswa dan meningkatkan kepercayaan diri sendiri. Sehingga dalam proses pembelajaran ini siswa lebih banyak belajar sendiri, mengembangkan kreativitas dalam memecahkan masalah. Siswa benar-benar ditempatkan sebagai subjek yang belajar. Keterlibatan aktif siswa terbukti dapat meningkatkan hasil belajar siswa dan sikap siswa terhadap suatu pelajaran.

Dalam model pembelajaran ini memiliki langkah-langkah yang mana setiap langkah mampu mengatasi kesulitan dalam mempelajari fisika 


\section{METODE PENELITIAN}

Penelitian ini merupakan penelitian eksperimen dengan desain Pretest-Posttest Control Group Design. Populasi dalam penelitian ini adalah seluruh siswa kelas X semester II SMA Negeri 11 Medan tahun ajaran 2014/2015. Sampel yang digunakan adalah kelas $\mathrm{X} \quad 3$ sebagai kelas eksperimen dan kelas X 4 sebagai kelas kontrol. Variabel bebas dalam penelitian ini adalah model Problem Based Learning (PBL) dan model pembelajaran konvensional sedangkan variabel terikatnya adalah hasil belajar pada materi pokok Suhu dan Kalor siswa SMA Negeri 11 Medan kelas X semester II tahun ajaran 2014/2015.

Sebelum diberi perlakuan, kedua kelas diberi pretes. Pembelajaran dilakukan dengan menerapkan model berdasarkan masalah untuk kelas ekspeminendan model pembelajaran konvension untuk kelas kontrol.

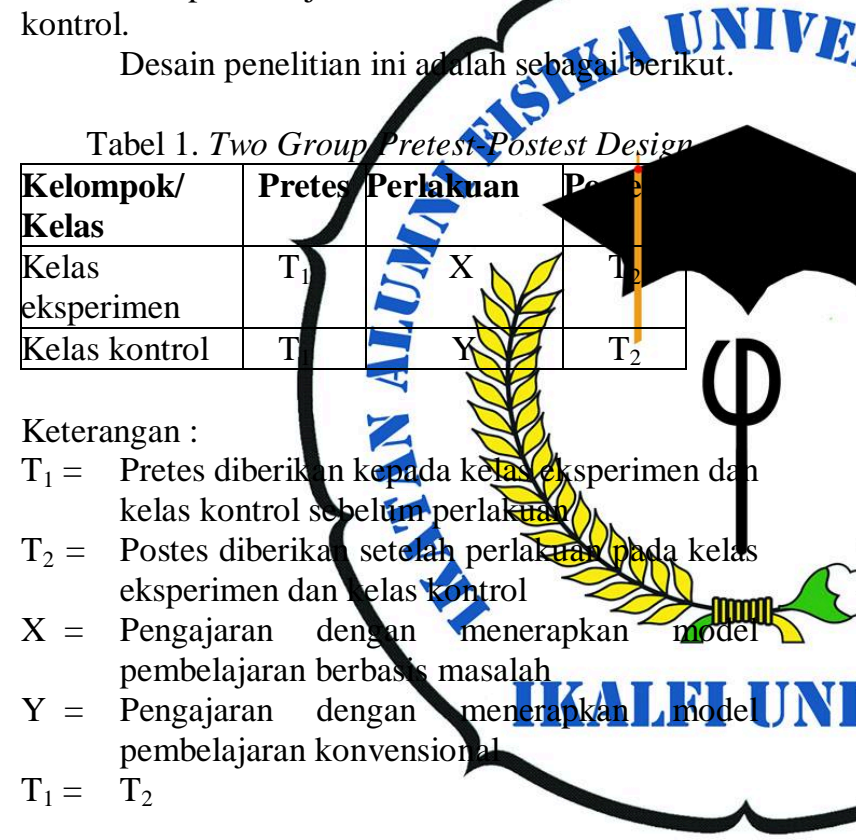

\section{HASIL DAN PEMBAHASAN}

\section{Pengolahan dan Analisa Data}

Sebelum dilakukannya penelitian, tes yang akan diberikan kepada sampel terlebih dahulu divalidkan. Pengujian validitas isi tes diperiksakan kepada tiga orang validator yaitu: 1) Drs. Ratelit Tarigan, M.Pd (Dosen Jurusan Fisika UNIMED), 2) Dr. Makmur Sirait, M.Si (Dosen Jurusan Fisika UNIMED), dan 3) Siti Saleha Lubis, S.Pd.,M.Si (Guru bidang studi fisika di SMA N 11 Medan) .Selanjutnya dari hasil validasi oleh validator, tes diuji cobakan kepada 36 siswa kelas XI untuk mengetahui validitas dan reliabilitas tes.

Dari hasil uji validasi dengan jumlah responden 36 siswa dengan merumuskan korelasi product moment, dari 25 butir soal terdapat 20 soal dinyatakan valid. Dengan demikian peneliti hanya mengambil jumlah item soal yang dinyatakan valid dan membuang item soal yang dinyatakan tidak valid. Selanjutnya, untuk menguji reliabilitas tes digunakan rumus Alpha Cronboach diperoleh $\mathrm{r}_{\text {hitung }}=$ 0,771 sedangkan $\mathrm{r}_{\text {tabel }}$ pada $\mathrm{n}=40$ dan $\alpha=0,05$ didapat 0,312 sehingga $r_{\text {hitung }}>r_{\text {tabel }}$ maka tes ini mempunyai reliabilitas tinggi .

\section{$>\quad$ Data Pretes}

Sebelum materi diajarkan, terlebih dahulu siswa diberikan pretes untuk mengetahui kemampuan awal siswa terhadap materi yang diteliti pada kelas eksperimen dan kelas kontrol.

Dari hasil pre-test kelas eksperimen diperoleh nilai terendah 20,00 , nilai tertinggi 55,00, nilai ratarata 39,5 dan simpangan baku 8,07 . Sedangkan pada kelas kontrol diperoleh nilai terendah 20,00 dan nilai tertinggi 50,00 dengan nilai rata-rata 38,25 dan simpangan baku 7,64.

\section{$>\quad$ Data Postes}

Setelah diberikan pretes pada kedua kelas maka penelitian dilanjutkan dengan memberikan perrakuan yang berbeda. Pada kelas eksperimen diterapka model pembelajaran berdasarkan masalah difaktan ovh peneliti, sedangkan pada kelas kontrol 'diterak kan pembelajaran konvensional dilakukar gteh pe eliti juga. Dikedua kelas kegiatan mbelajaran dilakukan sebanyak enam kali imuan.

Selanjutwya telah diberikan pembelajaran

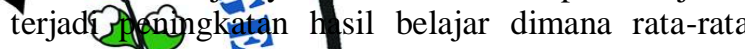
hasil betoyar siswa-sebe sar 76,63 dan standar deviasi 7,54 dengon-anilai tertin gi 90 dan terendah 55.

kelas kontrol diperoleh dimarataratat helajar siswa sebesar 67,63 danfor) Andar detrasi o 3 dengan nilai tertinggi 85 dan feretiab 45

Analisis Data Kelas Eksperimen Dan Kelas Kontrol

\section{A) ¿ Uji Nomalitas}

Unt ( $\mathrm{k}$ menguji normalitas data digunakan uj s yang bertujuan untuk mengetahui apakah penyebaran data hasil belajar siswa memiliki sebaran data yang berdistribusi normal atau tidak. Sampel berdistribusi normal jika dipenuhi $\mathrm{L}_{0}<\mathrm{L}_{\text {tabel }}$ pada taraf signifikan $\alpha=0,05$.

Berdasarkan hasil perhitungan uji normalitas, data tes pada kelas eksperimen untuk nilai pretes dan postes diperoleh hasil sebagai berikut: untuk data pretes diperoleh $\mathrm{L}_{0}<\mathrm{L}_{\text {tabel }}$ yaitu $0,126<0,140$ maka dapat disimpulkan bahwa sebaran data pretes dikelas eksperimen berdistribusi normal. Untuk data postes diperoleh $\mathrm{L}_{0}<\mathrm{L}_{\text {tabel }}$ yaitu $0,112<0,140$ maka dapat disimpulkan bahwa sebaran data postes dikelas eksperimen berdistribusi normal. Sedangkan data tes pada kelas kontrol untuk nilai pretes dan postes diperoleh hasil sebagai berikut : untuk data pretes diperoleh $\mathrm{L}_{0}<\mathrm{L}_{\text {tabel }}$ yaitu $0,109<0,140$ maka dapat disimpulkan bahwa sebaran data pretes dikelas kontrol berdistribusi normal. Untuk data postes diperoleh $\mathrm{L}_{0}<\mathrm{L}_{\text {tabel }}$ yaitu $0,137<0,140$ maka dapat disimpulkan bahwa sebaran data postes dikelas kontrol berdistribusi normal. 


\section{$>\quad$ Uji Homogenitas}

Pada uji normalitas diperoleh bahwa sampel berasal dari distribusi normal, maka langkah selanjutnya adalah uji homogenitas. Pengujian homogenitas data untuk mengetahui apakah sampel yang digunakan dalam penelitian berasal dari populasi yang homogen atau tidak. Maksudnya apakah sampel yang dipilih dapat mewakili seluruh populasi yang ada. Uji homogenitas yag digunakan adalah uji $\mathrm{F}$ dengan $\alpha=0,05$, dk pembilang $=36$ dan $\mathrm{dk}$ penyebut $=36$. Kriteria pengujian homogenitas yang harus dipenuhi adalah $\mathrm{F}_{\text {hitung }}<$ $\mathrm{F}_{\text {tabel. }}$.

Berdasarkan hasil perhitungan uji homogenitas pada data pretest diperoleh $\mathrm{F}_{\text {hitung }}<$ $F_{\text {tabel }}$ yaitu 1,534 < 1,744, maka dapat disimpulkan bahwa pretes kedua sampel berasal dari varians yang homogen, pada data postes diperoleh $F_{\text {hitung }}<F_{\text {t }}$ yaitu $1,135<1,744$, maka dapat disimpulkan oahwa postes kedua sampel berasal dari va lans yang homogen.

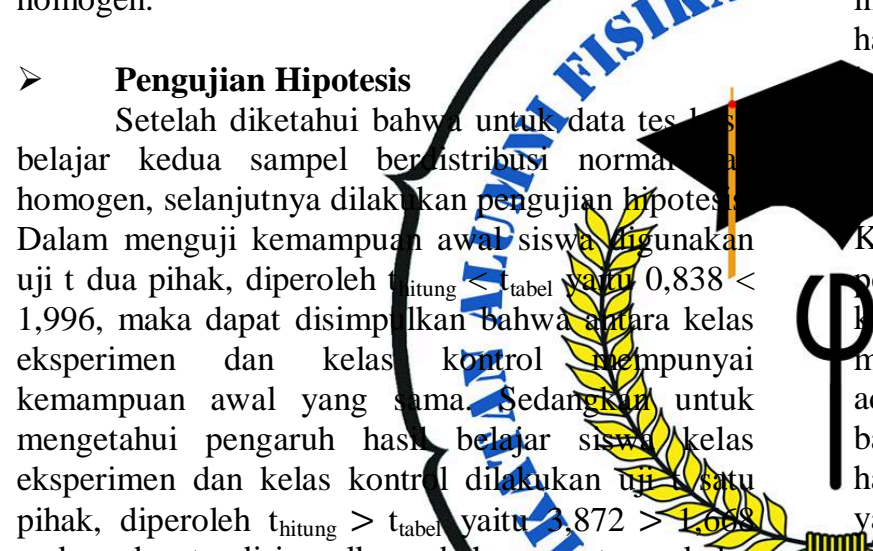

maka dapat disimpulkan eksperimen dan kelas kemampuan awal yang sama. Pembahasan
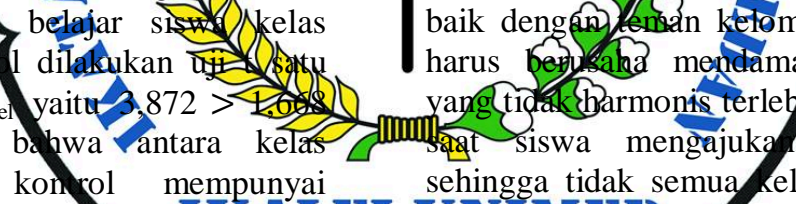

siswa dan siswa dengan guru, siswa terlatih untuk mengembangkan keterampilan komunikasi sosial,mendorong siswa menghargai pendapat orang lain,dan meningkatkan kemampuan akademik siswa serta melatih siswa untuk berbicara di depan kelas.

Lebih lanjut, pelaksanaan pembelajaran ini terfokus pada lima komponen utama model Problem Based Learning yaitu :1) Orientasi siswa pada masalah; 2) Mengorganisasikan siswa untuk belajar, setiap siswa diajak untuk mengelompokkan diri ke teman lainnya untuk dapat menyelesaikan masalah bersama; 3) Membantu menyelidiki secara mandiri atau kelompok, siswa berusaha untuk mencari penyelesaian masalah; 4) Mengembangkan dan menyajikan hasil kerja,setiap kelompok yang sudah mampu memecahkan masalah harus dipresentasikan untuk melatih siswa berbicara di depan kelas; 5) Menganalisa dan mengevaluasi hasil pemecahan masalah, siswa mampu menganalisa setiap penjasan masalah yang dikemukakan oleh teñankelompok ya. Pelaksanaan kelima komponen inilakyang menyeb bkan siswa lebih aktif, sehingga hasil belajar sisya le in tinggidibandingkan kelas

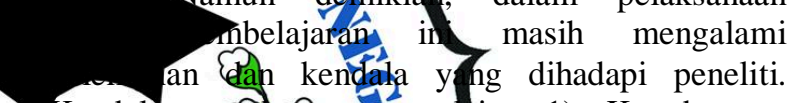
Kendala tersebut antara in: 1) Keterbatasan

peneliti datay mengald kasikan pembagian lelompok sis dalam kelompok belajar membutuhkan arktu yang 1 ma ditambah dengan adanya sisw baik deng(an) and ketompeknya sehingga peneliti harus betylán mendâma kan anggota kelompok yang tiar siswa mengajuka hasil diskusi mereka sehingga tidak semua kelompok dapat menyajikan hasir diskusi perera. 2) kurangnya pengalaman peneliti dalam nngelola kelas sehingga kondisi siswa yano nout menyebabkan penelitian menjadi

Hasil penelitian menunjukkan bahwa hastr efisien.

belajar siswa dengan menggunakan model pembelajaran berdasarkan masalah lebih baik dibandingkan dengan hasil belajar siswa dengan menggunakan model pembelajaran konvensional, hal ini dapat dilihat dari hasil postes kelas eksperimen memperoleh nilai rata-rata 76,63 , sedangkan hasil postes kelas kontrol memperoleh nilai rata-rata postes 67,63 . Peningkatan hasil belajar terjadi pada kelas eksperimen maupun kontrol, namun peningkatan terbesar terjadi pada kelas eksperimen. Peningkatan hasil belajar menggunakan model Problem Based Learning lebih baik dikarenakan model pembelajaran ini memiliki beberapa kelebihan yaitu model pembelajaran lebih berpusat pada siswa sehingga siswa lebih aktif untuk mengkonstruksi langsung pengetahuan melalui setiap kegiatan yang telah dirancang pada fase PBL dan juga semua anggota kelompok wajibmendapat tugas. Hal ini menyebabkan setiap anggota kelompok aktif, ada interaksi antara siswa dengan

\section{Apabila}

langkah-langkah

model pembelajaran berdasarkan masalah dapat dilakukan seefektif mungkin dan kendala-kendala dapat diatasi maka model pembelajaran PBL dapat dijadikan salah satu model pembelajaran yang dapat memperbaiki hasil belajar fisika siswa.

Di samping itu, peneliti sudah berusaha mengatur waktu sesuai dengan yang direncanakan dalam RPP, namun dalam pelaksanaan pembelajaran di dalam kelas, peneliti masih menemukan kekurangan waktu dikarenakan di dalam pelaksanaan diskusi memerlukan waktu yang lama. Maka dalam hal ini penggunaan waktu sangat penting untuk diperhatikan oleh guru di dalam pembelajaran sehingga dapat memaksimalkan pencapaian hasil belajar.

Maka bagi peneliti selanjutnya yang ingin meneliti masalah yang sama ada baiknya terlebih dahulu memotivasi siswa dengan mengarahkan kepada siswa agar setiap tim dapat berdiskusi 
dengan baik karena nilai dari satu orang siswa dapat mempengaruhi nilai kelompok tersebut, serta memberikan penghargaan pada siswa yang aktif dalam mempresentasekan hasil diskusi dengan memberikan nilai tambahan kepada siswa tersebut. Kemudian menghargai jawaban atau hasil presentase dengan mengucapkan terima kasih kepada siswa untuk meningkatkan rasa percaya diri siswa.

\section{KESIMPULAN DAN SARAN \\ Kesimpulan}

Dari hasil analisis yang dilakukan dalam penelitian ini diperoleh kesimpulan yaitu Hasil belajar siswa yang diajar dengan model Problem Based Learning (PBL) setelah diberikan perlakuan diperoleh ratarata nilai postes siswa sebesar 76,63 dengan kriteria tuntas. Hasil belajar siswa yang diajar dengan pembelajaran konvensional setelah dibemilun perlakuan diperoleh rata-rata nilai postes siswa sebesar 67,63 dengan kriteria pengaruh hasil belajar sisw model Problem Based Lea $>\mathrm{t}_{\text {tabel }}=4,84>1,667$ 0,05 .

\section{Saran}

Kepada peneliti se penelitian yang dengan jelas masal sehingga siswa leb kondisi kelas lebih Kepada peneliti selanjutnya, memperhatikan peng unaan waktu dom kel s

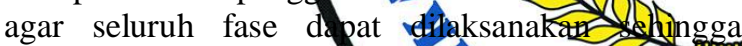
kompetensi yang diharap an dapat tercapai. cilmom Kepada guru sebaiknya nenggunakan model PBL karena dapat meningkatka hasil belajar, dapat JNINIJ) dilihat dari hasil belajar siswa pada kelas eksperimen, rata-rata pretes siswr 39,5 setelah diajarkan dengan PBL rata-rata postes siswanmenjud 76,63 .

\section{DAFTAR PUSTAKA}

Arends, R. I., (2013), Learning to teach, Humanika Salemba, Yogyakarta.

Balitbang.,(2011). Survei Internasional TIMSS (Trends In International Mathematics and Science Study).[Online] http://litbang.kemdikbud.go.id/detail.php?id=214, diakses 23 Februari 2015

Dalyono,M., (2005), Psikologi Pendidikan, Rineka Cipta, Jakarta

$\begin{array}{rrr}\text { Trianto, (2012), } & \text { Mendesain } & \text { Model-Model } \\ \text { Pembelajaran } & \text { Inovatif } & \text { Berorientasi }\end{array}$ Konstruktivistik, Prestasi Pustaka, Jakarta.

Kennedy, (2009), Perbedaan Hasil belajar Siswa Menggunakan Model Pembelajaran Berbasis Masalah (Problem Based Learning ) dengan Konvensional pada Materi Pokok Pemuaian

di SMA Negeri 4 Kisaran T.A. 2008/2009. Skripsi, FMIPA, Unimed, Medan

Siagian, L, (2009), Perbedaan Hasil Belajar Siswa Menggunakan Model Berdasarkan Masalah dan Model Pembelajaran Konvensional pada Materi Pokok Listrik Dinamis di Kelas IX SMP N 2 Rantau Parapat T.A 2008/2009. Skripsi, FMIPA, Unimed, Medan

Sihotang, I. M, (2012), Perbedaan Hasil Belajar Siswa dengan Model Pembelajaran Berbasis Masalah dan Konvensional pada Materi Pokok Optik Geometri Kelas X SMA St. Yoseph, Medan. Skripsi, FMIPA, Unimed, Medan

Siregar, D. S, (2011), Pengaruh Model Pembelajaran Berdasarkan Masalah dalam Meningkakan Aktivitas Belajar Dan Pemahaman Konsep Siswa Pada Materi Pokok Kinematika Gerak Lurus Di Sekolah Menengah Atas Kelas X. Skripsi, FMIPA, O imed, Medan gang, (2012), Pengaruh Model Pembelas ran Berbasis Masalah Terhadap Hasit,Belds r Siswa pada Materi Kesetimbans on Benda Tegar Kelas XI MAN 1 Medân T.P $011 / 2012$, Skripsi, FMIPA, Unimed Meda
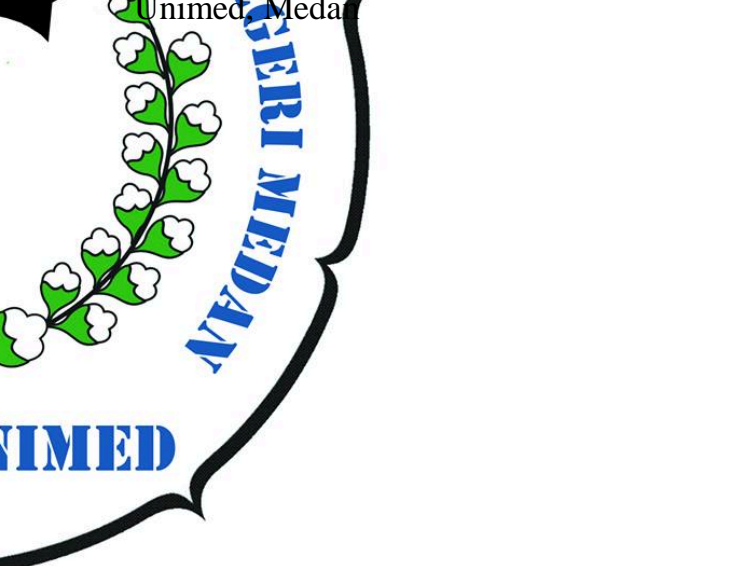